\title{
PLATÃO TRÁGICO E ANTITRÁGICO
}

\author{
ROBERTO BOLZANI FILHO \\ Faculdade de Filosofia, Letras e Ciências Humanas \\ Universidade de São Paulo
}

Para Filomena, que me ensinou a apreciar os trágicos, do eterno admirador e aluno.

Resumo: Este texto pretende analisar o conhecido relato do Oráculo de Delfos na Apologia de Sócrates, como um caso exemplar de um procedimento tipicamente platônico de retomar formas discursivas tradicionais, para criticar a visão de mundo que as fundamente, de modo a defender suas próprias ideias e filosofia.

Palavras-chave: Filosofia, tragédia, divindade.

Na Apologia de Sócrates de Platão, toda a defesa do filósofo, incluindo-se aí heroicas recusas a reconhecer qualquer culpa e a desistir de sua vida e atividade filosóficas, se sustenta sobre sua convicção de que tudo o que tem feito na cidade - interrogar os supostos e pretensos sábios e exibir seus falsos saberes - consiste na execução de uma missão que lhe foi conferida pelo deus, num auxílio que presta à divindade, obedecendo assim seu comando, sempre em benefício da cidade, dos homens e de si mesmo. Ele se diz um soldado posicionado pelo deus, para "viver filosofando e inspecionando a mim mesmo e aos outros", soldado que não pode abandonar seu posto, nem mesmo sob o risco de morte, nisso lembrando Aquiles em Tróia (28c-e). Ele não poderá sequer negociar por sua vida, se para isso tiver de ceder, em troca, o abandono de sua filosofia, pois isso significaria desobediência ao deus, algo que lhe parece inadmissível: "obedecerei antes ao deus que a vocês e, enquanto respirar e tiver condições, receio não parar de filosofar...Pois é isso fiquem sabendo - que o deus me ordena, e eu mesmo penso que ainda não surgiu para vocês nenhum bem maior na cidade do que meu serviço ao deus!” (29d-30a) ${ }^{1}$.

1 A tradução da Apologia de Sócrates citada aqui será a de Platão, 2008. O texto grego é o de Platão, 1970. 
Sócrates é, assim, ligado à cidade pelo deus, como uma dádiva a ela conferida (30e, 31a), e matá-lo será, então, enorme malefício que a cidade produzirá contra si própria (30c).

Pedir a Sócrates que deixe de filosofar é pedir-lhe que, desobedecendo ao deus, deixe de ser Sócrates, é querer que viva uma vida indigna, porque desprovida de exame e investigação (38a). É exigir dele algo que lhe parece mesmo impossível, porque esse abandono, na verdade, não está ao seu alcance: suporia que o filósofo fosse capaz de uma transformação absolutamente radical. De fato, ele deixa claro que, se for condenado, o será por ser "desse jeito que digo que sou" (toioûton ónta hoîon egò légo) (30c), "sendo desse jeito" (toioûtos ón) (36d)². Não são seus atos que movem a acusação no tribunal, é seu ser. E sua obediência ao deus está de tal forma associada ao fato de ser ele tal como é, que não parece nada fácil compreender com clareza como se relacionam e separam sua existência e esse exercício contínuo de obediência. $\mathrm{O}$ obstinado apego que fundamenta sua defesa não é à vida, é à sua condição de missionário divino. Assim, seu modo de ser está profundamente relacionado à experiência que o transformou nessa dádiva do deus.

Eis por que todo o conteúdo da defesa do filósofo no tribunal, tal como se pode ler na Apologia platônica, tem como centro de gravidade as célebres páginas em que se narra o acontecimento maior de sua vida: o episódio do Oráculo de Delfos. Nele, compreendemos como se dá a experiência pessoal de um Sócrates que, inicialmente incapaz de atinar com o oráculo divino, descobre finalmente que está a serviço do deus. São, sem dúvida, as páginas filosoficamente mais significativas e densas do discurso socrático e, em sentido importante, consistem na inauguração da filosofia do mestre, tal como o discípulo quer apresentá-la à posteridade. Nelas germinam alguns procedimentos que os diálogos ditos "socráticos" de Platão vão pôr em ação e que essa mesma posteridade vai eleger como essenciais para a elaboração da própria ideia de racionalidade: o exame rigoroso e crítico de teses a princípio aceitas apenas por autoridade e tradição, a interrogação e a dúvida deliberadas como elementos indispensáveis a uma investigação consistente, obediência estrita a exigências lógicas e dialéticas.

Isso certamente é correto, mas há sempre o risco de se perder de vista outros aspectos importantes desse episódio inaugural. Um deles está justamente naquela relação entre o filósofo e o deus, entre o humano e o divino, que uma leitura mais apressada bem poderia deixar em segundo plano ou até mesmo ignorar, em benefí-

2 31a: Toioûtos állos ...egò tygkháno òn toioûtos hoîos...; 33a: toioûtos... ho autòs hoûtos. 
cio dessa emergente racionalidade, que não tardará a ser reduzida a uma "questão de método". Contudo, há aí muito mais: sendo a defesa de uma nova maneira de pensar, o socratismo da Apologia, para tanto, precisa, ao mesmo tempo, estabelecer também uma maneira, se não absolutamente inédita, ao menos surpreendente aos olhos da tradição mais remota, de compreender a relação entre o humano e o divino. Somente assim, com essa dupla tarefa vencida, pode-se compreender por que o filósofo incorpora em seu modo mesmo de ser o serviço à divindade. Trata-se aqui de comentar como Platão dá conta dessa dupla tarefa, pois isso nos esclarece algumas características fundamentais de sua filosofia, particularmente a respeito de sua maneira de veicular, em face da tradição, o tipo de lógos que seu mestre lhe inspira.

A narrativa do episódio em Delfos pretende persuadir os juízes e os leitores da Apologia de que Sócrates nele encontrou o verdadeiro sentido para sua existência, de que se tratou ali de uma descoberta profundamente significativa e decisiva para sua vida. Para isso, há elemento importante da narrativa que nem sempre é levado em conta ou é destacado devidamente: a temporalidade dos acontecimentos, o fato de que eles devem ser compreendidos numa sucessão de atos e pensamentos concatenados. A relativa brevidade do relato não nos deve fazer perder de vista que, após tomar conhecimento da resposta oracular, que afirmara a Querefonte que ninguém era mais sábio do que ele (21a), Sócrates afirma ter ficado muito tempo em aporia (polùn khrónon epóroun) e, depois disso, a muito custo (mógis pány), decidiu-se a refutar (elégxon) o oráculo, já que "bem sei comigo mesmo (egò...sýnoida emautô(i)) que não sou sábio" (21b-c).

Essa dificuldade revelada por Sócrates, sua demora na tentativa de compreensão do dito oracular e sua custosa decisão de confrontá-lo, é fundamental para apreender plenamente o significado de todo o episódio. Nisso se exibe toda a complexidade de nosso filósofo: reconhecendo a absoluta superioridade divina, ele apresenta, inicialmente, uma disposição piedosa que o iguala aos homens em geral; contudo, imediatamente vê na sentença oracular a negação de uma verdade interior, segundo a qual ele não é e não pode ser sábio. Instala-se aí, para ele, mais do que uma aporia no sentido lógico da ideia, um autêntico conflito existencial, a confrontar duas verdades, à primeira vista, irrecusáveis: a sua, meramente humana, mas sua, dotada da qualidade e da autoridade de dizer respeito apenas a ele, à qual, portanto, ele tem claro e imediato acesso, e a divina, que deve ser verdadeira por definição, já que ao deus não é lícito mentir (21b). 
Tal confronto, a meu ver, autoriza a que se faça alusão a uma característica que, como se sabe, é típica da tradição épica e da tragédia, nela inspirada, em que o humano se vê sempre às voltas com o divino e só é capaz de compreender sua condição efêmera à luz desse mesmo divino e de sua superioridade. No caso da tragédia, sabemos que, via-de-regra, se desenvolve tendo seu momento crucial numa ação humana que desrespeita, desafia e afronta alguma determinação ou vontade divina, cometendo-se aí um erro que frequentemente condena o agente, de forma irremediável, à punição. Tal ação se configura, portanto, como hýbris, como hamartía $^{3}$. A arrogância, a desmedida e a ousadia humanas, revestidas de diferentes roupagens, dão ao tragediógrafo o material para a elaboração de uma trama de ações e discursos, da qual se espera, ao fim e ao cabo, que o divino reafirme seu poder e saber.

Ora, mesmo com essa descrição grosseira e certamente parcial do mecanismo básico da tragédia, pode-se ao menos concluir, olhando novamente para nosso episódio da Apologia, que, em seu momento inicial, Sócrates, ainda que a custo, ao resolver desafiar o oráculo de Apolo, executa ação característica do protagonista trágico. Ação arrogante, ousada, desmedida e, por isso mesmo, ímpia. Digamos então que a narrativa socrática do episódio do Oráculo contém, em seu início, uma espécie de anticlímax ímpio, que o leitor contemporâneo de Platão, conhecedor das tragédias e de seu funcionamento, formado nos poemas homéricos e suas divindades intempestivas e frequentemente implacáveis, saberá identificar e associar a essa já tradicional produção discursiva de sua época.

Dois comentários devem aqui ser feitos. Em primeiro lugar, é preciso observar que o gênero trágico lida com uma visão de mundo típica do chamado período homérico ou mundo homérico, em que a presença do divino se percebe em toda parte e em toda parte é esperada, na natureza como no homem, dando a tudo isso um sentido que este é capaz de constatar, mesmo quando não consegue compreender, e que deve, portanto, aprender a reafirmar no culto piedoso. Ainda que os trágicos se sirvam dessa ideia para, muitas vezes, ir além dela, mobilizando temas e preocupações de sua própria época, até mesmo conferindo, com objetivos próprios, novos significados e intenções aos mitos tradicionais, o gênero não pode prescindir desse esquema básico, que torna possível o mecanismo da tragédia e seu efeito. E quando lemos a narrativa do episódio de Delfos na Apologia, temos então o direito de interpretar suas linhas iniciais, desde o conhecimento do conteúdo da resposta

3 Grosso modo, o vocabulário predominante nas tragédias, para referir-se a tais situações e atitudes, parece girar em torno desses substantivos e verbos correspondentes. 
oracular até o dilema socrático e sua decisão ímpia, como uma forma que Platão, o autor do texto, encontra para dialogar com o gênero trágico e emulá-lo.

Em segundo lugar, olhando agora para o texto da Apologia como um todo, cabe lembrar que uma das acusações que pesa sobre Sócrates é a de impiedade - de "não crer nos deuses em que a cidade crê, mas em coisas numinosas diferentes, novas" (24b). Isso pode provocar no leitor a sensação de que Sócrates, como defensor de sua causa, não se sai nada bem, já que está, até aqui, confirmando a impiedade que lhe é imputada. Mas trata-se apenas de um anticlímax ímpio, que é, em verdade, absolutamente necessário, pois esse momento do relato é também a ocasião para mostrar ao leitor o "jeito" de Sócrates, aquele mesmo jeito que, como vimos, ele alegará em seu favor, quando se recusar a fazer qualquer concessão de natureza filosófica em benefício de sua própria sobrevivência. Note-se que Sócrates é levado, ainda que a muito custo, a tentar refutar o oráculo, porque está profundamente convencido de que nada sabe - e isso, como vimos, ele diz "saber consigo mesmo" (21b). A exibição da arrogância socrática é, ao mesmo tempo, a construção do alicerce principal daquilo que a posteridade chamará de "socratismo": o valor do autoconhecimento. E não pode haver forma mais eficaz de expressar esse valor, do que sobrepô-lo, ao menos de início, à autoridade divina, conferindo à "interioridade" humana o direito de questionar a verdade objetiva que se atribui a qualquer fala de um deus. Eis por que Sócrates ousa pretender aplicar na sentença oracular o mesmo procedimento que, mostram-no os vários diálogos ditos "socráticos" e a própria sequência de nossa narrativa, aplica em qualquer um que se julga ou é julgado "sábio". O divino foi, agora, de certa forma, reduzido ao humano, sua fala é tão duvidosa quanto a de um homem qualquer. Inaceitável hýbris, que deve produzir no ouvinte do tribunal e no leitor do texto impacto semelhante ao das tragédias, simultaneamente introduzindo elemento fundamental do modo socrático de ser.

Desse ponto de vista, que enxerga o relato platônico à luz do mecanismo da tragédia, não me parece absurdo arriscar uma comparação, ainda que anacrônica: o que Platão faz, nessas linhas iniciais do relato do episódio de Delfos, é razoavelmente compatível com algumas das principais características que Aristóteles, em sua Poética, vai conferir à tragédia ${ }^{4}$. A imitação elaborada pelo poeta trágico, dirá

4 Esse perigoso procedimento de evocar a Poética de Aristóteles para comentar um trecho de Platão será empregado com alguma frequência aqui. Evidentemente, não se pretende sustentar a tese de que a elaboração do episódio do Oráculo de Delfos da Apologia se explica impecavelmente pelos preceitos aristotélicos, como se Platão os conhecesse. É claro que 
Aristóteles, faz com que a ação (práxis) imitada seja reveladora do pensamento (diánoia) do agente e, consequentemente, de seu caráter (êthos), conferindo-se assim diversas qualificações às ações. Pensamento e caráter serão, assim, causas das ações 5 . Na Apologia, estamos talvez caminhando em sentido contrário, mas na mesma direção. Sócrates revela os pensamentos que tem ao ouvir a sentença divina - aquilo que "pensou consigo mesmo", sua convicção pessoal e a aporia que se segue -, os quais o levarão a adotar um modo de agir - para investigar e refutar o oráculo, procurar os que são julgados sábios, examinando-os (21c), atividade que predomina em todo o relato (21d-e, 22a-b, 22c-d). Neste caso, para retomar a terminologia aristotélica, a práxis de Sócrates nos é apresentada como consequência de sua diánoia, o que em nada parece contrariar o esquema aristotélico, apenas inverte os papéis - se na tragédia, segundo Aristóteles, ficamos conhecendo as intenções do agente, seu pensamento e caráter, pela ação executada, no episódio socrático temos conhecimento das razões que movem a ação antes de conhecê-la ${ }^{6}$.

Platão não os conhecia. Contudo, é inimaginável que não fosse profundamente familiarizado com as tragédias, seja como espectador, seja como leitor - as mesmas tragédias de que parte Aristóteles para a elaboração de sua teoria. Isso, a meu ver, justifica o anacrônico expediente, embora não o isente de cautela e, sobretudo, de evitar aproximações excessivas.

5 A passagem central a esse respeito é 1449b36-1450a7: "E como a tragédia é a imitação de uma ação e se executa mediante personagens, que agem necessariamente conforme o próprio caráter e pensamento (hoùs anágke poioús tinas eînai katá te tò êthos kaì tèn diánoian) (porque é segundo estas diferenças de caráter e pensamento que qualificamos as ações (kaì tàs práxeis eînaí phamen poiás tinas), daí vem por consequência o serem duas as causas naturais que determinam as ações (aítia dýo tôn práxeon): pensamento (diánoia) e caráter (êthos); e, nas ações [assim determinadas], tem origem a boa ou má fortuna dos homens. Ora o mito é imitação de ações; e por 'mito' entendo a composição dos atos; por 'caráter' (tà éthe), o que nos faz dizer das personagens que elas têm tal ou tal qualidade (poioús tinas eînai); e por 'pensamento' (diánoian), tudo quanto dizem as personagens para demonstrar o que quer que seja (apodeiknýousín ti) ou para manifestar sua decisão (apophaínontai gnómen)”. Tradução em Aristóteles, 1973, ligeiramente modificada. Para o texto grego, Aristóteles, 1974.

6 Para Aristóteles, sendo a tragédia imitação de ação e de vida, de felicidade e infelicidade nas ações, o caráter deve tornar verossímil a ação, mas o que importa, acima de tudo, é a "trama dos fatos" (he tôn pragmáton sýstasis), tornando-se as ações e o mito a finalidade (télos) da tragédia. Isso acarreta consequência importante para compreender o papel do êthos: "daqui se segue que, na tragédia, não agem as personagens para imitar caracteres (oúkoun hópos tà éthe mimésontai práttousin), mas assumem caracteres para efetuar certas ações (tà éthe symperilambánousin dià tàs práxeis)" (1450a15-23). O êthos do agente colabora na sýstasis das ações, mas não é visado, não é visto como finalidade. Aqui estará talvez uma diferença importante na comparação com nosso episódio da Apologia, na qual o 
E isso não é ocasional, pois se trata, sobretudo, de dar à "interioridade" de Sócrates o papel de ponto de partida de sua atuação. Mais uma vez, deve-se ver nisso a tentativa de expressar a particularidade e especificidade de nosso filósofo, perante a visão corrente: tomando suas próprias convicções como porto seguro, ele vai recorrer àqueles que "parecem ser sábios" (tôn dokoúnton sophôn eînai), sobre os quais predomina uma opinião pública e comum que lhes confere essa condição e reputação, pensando, nesse momento, neles encontrar aliados para sua refutação do oráculo, aos poucos descobrindo, contudo, que seu verdadeiro conflito é com essa opinião comum. Seja como for, com tudo isso é certo que o "jeito" de Sócrates é revelado ao leitor pelo seu modo de pensar e pela ação que disso decorre, e que esse "jeito" é o análogo, no episódio, àquilo que, na tragédia, o Estagirita considera executar a função de êthos da personagem ${ }^{7}$. E o caráter socrático, digamos assim, veicula o elogio da reflexão e da investigação, algo que, nesse momento, justifica até mesmo a recusa ao cego assentimento à autoridade divina ${ }^{8}$.

Essa investigação é, ao mesmo tempo, uma auto-investigação, pois, a cada vez que examina um pretenso sábio e descobre que tal saber não se sustenta, constatando que tem a vantagem da consciência de sua ignorância (21d, 22c, 22e), Sócrates conhece melhor o valor desse saber, passando a vê-lo, aos poucos, como apenas aparentemente negativo. E o desenrolar dos acontecimentos relatados por

“jeito” socrático é o alvo central da narrativa. É verdade, contudo, que em certo sentido o caráter paradigmático de Sócrates também envolve um modo de vida e de ação, como o filósofo não se cansará de destacar diante de seus juízes.

7 As diferenças com a Poética não impedem de ver no momento inicial do episódio aproximações com a maneira como esse tratado entende as noções de êthos e diánoia: "caráter (êthos) é o que revela certa decisão (delô̂ tèn proaíresin) ou, em caso de dúvida (hopoía tis em hô̂s ouk ésti dêlon), o fim preferido ou evitado (è proaireîtai è pheúgei); por isso não têm caráter os discursos do indivíduo em que, de qualquer modo, se não revele o fim para que tende ou o qual repele. Pensamento (diánoia) é aquilo em que a pessoa demonstra que algo é ou não é, ou enuncia uma sentença geral (kathólou ti apophaínontai)" (1450b4-13). A decisão socrática de refutar o oráculo diz a respeito de seu caráter, expresso em seu pensamento.

8 Evidentemente, como estamos em pleno tribunal, a análise do discurso socrático pede naturalmente um cotejo com preceitos próprios da retórica, sobretudo porque também nela se destaca uma noção de êthos. Mais uma vez, pode-se recorrer a Aristóteles, que vê no êthos do orador a prova mais autorizada (kyriotátes pístis) para torná-lo digno de confiança (axiópiston). O discurso deve elaborar, sem prévia opinião suposta, a qualidade moral do orador (he epieíkeia toû légontos) (cf. Aristóteles, 1975, 1356a 4 e segs.). Contudo, isso não invalida que o episódio do Oráculo possa comportar referências a outras formas discursivas, como a poesia, épica ou trágica. O fato de um conceito de êthos operar tanto na Retórica quanto na Poética de Aristóteles é, ao menos, indício em favor dessa possibilidade. 
Sócrates vai conduzir o leitor a observar uma gradativa mudança em suas verdades e convicções pessoais. Conforme vai investigando os supostos sábios da cidade políticos, poetas e artesãos -, Sócrates vai descobrindo que eles não possuem o saber que se lhes atribui a respeito do que é belo e bom, e que ele, que também nada sabe, sabe ao menos que nada sabe, enquanto eles, passando a odiá-lo por contestar seus saberes, ignoram sua ignorância própria (21d, 22c, 22d-e, 23a). Nesse processo, cuja duração não é clara, mas certamente não é breve, Sócrates passa de contestador da sentença oracular a seu ferrenho e legítimo defensor. Compreende que a descoberta do não-saber humano a respeito do que mais importa ao homem é o que pode torná-lo sábio, configurando a verdadeira e simples sabedoria acessível a qualquer um.

Ora, para chegar a tal conclusão, Sócrates submeteu ao crivo do exame interrogativo - marca distintiva de sua atividade filosófica - tanto os sábios reconhecidos, como, indiretamente, o próprio deus. E somente se deixou convencer da verdade divina quando pôde compreendê-la do ponto de vista de seu critério próprio, essa interrogação e consequente possibilidade de refutação. Ao resistir a tal critério, tornando-se irrefutável (22a), a fala do deus se impôs e pôde assim ser plenamente compreendida pelo filósofo, que, ao mesmo tempo, manteve sua verdade interior - saber que nada sabe - e compreendeu que, diferentemente do que imaginava, ela não só não conflita com a sentença do deus, como também exibe um exemplo da verdade dessa sentença, confirmando-a. Eis por que o deus oferece Sócrates aos homens como um modelo (parádeigma), enquanto o filósofo, doravante uma dádiva divina, passa a ver sua interrogação refutativa como um serviço que presta ao deus, agora obedecendo-o incondicionalmente (23a-b).

Também esse notável desfecho pode ser compreendido pelo prisma da tragédia. Contudo, parece que, nesse caso, um nítido contraste se impõe. $\mathrm{Na}$ tragédia, sempre se trata de constatar e confirmar, pelos homens, a inconteste superioridade da verdade e vontade divinas, predominando o final punitivo e, por isso mesmo, trágico. $\mathrm{O}$ aprendizado ou descoberta dessa superioridade não é simples processo intelectual, sendo composto também de dor e sofrimento, em virtude de atitudes arrogantes e desafiadoras que os deuses não podem jamais admitir e tolerar. A hýbris humana necessariamente condena o agente à infelicidade, de diversas formas. No esquema aristotélico, há o reconhecimento de algo que revela a condição miserável que aguarda o agente. E o predomínio das determinações divinas faz apenas reiterar uma distância intransponível, cabendo ao homem respeitá-la, mesmo quando não a compreende - e raramente ele a compreende por completo. 
No episódio socrático, permanece verdadeiro que há uma grande distância entre o divino e o humano. E permanece verdadeiro que, quando procura suprimila, o humano, cedo ou tarde, a reencontra, reconhecendo-a. Mas o divino do episódio de Delfos não pune seu desafiante humano: bem ao contrário, concede-lhe o direito da tentativa de refutação, ainda que fadada ao fracasso, para que descubra, por seus próprios meios, que está submetido a esse mesmo divino, como era de se esperar. E a servidão de nosso filósofo ao deus, sua obediência consciente e deliberada, parece-lhe agora o que de melhor lhe poderia acontecer. Se ele se vê, doravante, como uma dádiva que o deus confere aos homens, ele próprio vê nessa descoberta uma dádiva que o deus lhe confere, e obedecê-lo, agora, não é oferecer sacrifícios ou mesmo sacrificar-se, mas sim manter-se exatamente como sempre foi. Não há mais conflito entre o humano e o divino, pois o estritamente humano investigar e refutar - é um aliado no plano divino - mostrar aos homens que nada sabem. Aqui, longe de confirmar o mecanismo da tragédia, o episódio de Delfos o contraria frontalmente. E àquele anticlímax ímpio do início, que nos sugeria um Sócrates incompetente como advogado de si mesmo contra a acusação de negar os deuses da cidade, segue-se um clímax piedoso, no qual, de forma talvez inesperada ao tribunal, nosso filósofo recupera sua relação de obediência ao deus9.

O episódio dá a Sócrates a oportunidade para conferir à sua vida um sentido que, até então, não possuía, porque lhe permite agora conciliar sua atividade filosófica com a determinação divina, de uma forma que não havia imaginado, sem ter que ceder ao divino os valores que sempre prezou, compreendendo que esses valo-

9 É preciso, evidentemente, cuidado ao afirmar-se que a tragédia consiste num conjunto de ações que desemboca na punição e infelicidade do agente humano. Levando-se em conta as tragédias conhecidas e os comentários de Aristóteles na Poética, que aludem a várias delas, muitas desconhecidas, é certo que isso não pode ser visto como necessário. Aristóteles nos diz, a respeito da extensão de uma tragédia, que deve ser suficiente para conter ações em sucessão, verossímeis, nas quais ocorra a passagem da infelicidade à felicidade (eis eutykhían ek dystykhías) ou da felicidade à infelicidade (ex eutykhías eis dystikhían)" (1451a11-15). Admite, portanto, a presença de resultados felizes. Contudo, parece entender que a passagem de felicidade à infelicidade - desde que nas adequadas condições de caráter, isto é, para alguém que não se destaca em virtude e justiça - é antes preferível: "é pois necessário que um mito bem estruturado seja antes simples do que duplo, como alguns pretendem; que nele não se passe da infelicidade para a felicidade (metabállein ouk eis eutykhían ek dystykhías), mas, pelo contrário, da dita para desdita (ex eutykhías eis dystykhían)...Por isso erram os que censuram Eurípides, por assim proceder nas suas tragédias, as quais, a maior parte das vezes, terminam em infortúnio (eis dystykhían). Tal estrutura, já o dissemos, é correta” (1452b30-1453a30). 
res, de fato, são aprovados e até promovidos pelo divino. Solicitar a um interlocutor que se submeta à interrogação é exigir dele que seu saber, para ser aceito como tal, resista à tentativa de refutação. Isso, agora Sócrates bem o sabe, é o que o deus deseja dele. Os acontecimentos de Delfos consistem na transformação de Sócrates, de um refutador convicto, mas ainda tateante, num filósofo autêntico e pleno. Por isso, eles conferem à sua vida e filosofia um significado que ainda não possuíam. Eis por que se pode afirmar que estamos perante a inauguração da filosofia socrática, tal como a veremos exercitada em vários diálogos de Platão.

$* * *$

Mas há que observar que todo esse engenhoso e sofisticado processo depende, na verdade, de uma reformulação da ideia mesma do divino. Somente um deus profundamente repensado em seu sentido poderia conferir ao homem o direito de desafiá-lo, para permitir-lhe o reconhecimento de sua condição. Somente um deus dotado de uma natureza essencialmente benfazeja veria nesse desafio o meio de conceder aos homens a oportunidade de realmente conhecerem-se a si mesmos em toda a sua ignorância, fazendo de Sócrates, não um arrogante desmedido que necessita de punição, mas um modelo a ser imitado, um exemplo positivo.

Por isso, ao mesmo tempo em que constrói a figura paradigmática do filósofo, o episódio parece também instaurar uma concepção do divino que, se não for absolutamente inédita, será ao menos substancialmente distinta daquela que opera destacadamente na tradição homérico-hesiódica e, consequentemente, na poesia trágica. Quando Sócrates reflete sobre o conteúdo do oráculo, a aporia em que se vê instalado resulta daquilo que, por um lado, sabe sobre si próprio, e, por outro lado, do próprio conteúdo do oráculo, que contraria tal saber, somado ao fato de que, ao deus, mentir (pseúdetai) "não é algo lícito" (ou...thémis autô(i)) (21b). Diante dessa última afirmação, é difícil deixar de pensar nos célebres versos de Hesíodo, no proêmio de sua Teogonia, quando as Musas se dirigem aos pastores no pé do monte Hélicon: "Pastores agrestes, vis infâmias e ventres só, sabemos muitas mentiras (pseúdea pollá) dizer símeis aos fatos, e sabemos, se queremos (ethélomen), dar a ouvir revelações (alethéa)" $(26-8)^{10}$. Aqui, o divino deixa claro que detém o poder de mentir e que o faz, quando deseja. E os poemas homéricos exibem diversos momentos em que os deuses, movidos por intenções variadas, iludem ou enganam os mortais. Tanto em Homero quanto em Hesíodo, essa capacidade é sinal de

10 Tradução em Hesíodo, 1986. 
superioridade: tão poderosos são os deuses, que não estão submetidos a limitações, como, por exemplo, ter sempre de dizer verdades, sob pena de punição. Ora, a esse respeito, o deus do episódio de Delfos depara com um limite, talvez mesmo uma interdição: sendo divino, não lhe cabe mentir. Não há como afirmar categoricamente se a lacônica passagem quer dizer que ele não pode mentir ou se quer dizer que, podendo mentir, não deve fazê-lo. Seja como for, constata-se aí claro afastamento da tradição.Sem essa mudança, o sentido positivo e benéfico de todo o episódio não seria claro e não poderia ser plenamente elaborado. Não é apenas o "jeito" de Sócrates que se expressa e constrói na narrativa, é também o caráter divino. Os acontecimentos mostram, na expressão aristotélica, o êthos de Sócrates e o apresentam como exemplo paradigmático. Esses mesmos acontecimentos elaboram ainda um êthos divino, talvez também com a mesma função exemplar e paradigmática. É importante observar que só sabemos que se trata do deus Apolo, porque a narrativa se inicia com Sócrates anunciando que trará ao tribunal como testemunha "o deus de Delfos" (tòn theòn en Delphoîs) (20e). O nome próprio do deus, contudo, nunca é mencionado, sempre ocorrendo a expressão "o deus" (ho theós) (21b, 21e, 23a, 23b-c). Não teria Platão aqui se servido do deus de Delfos, cujo lema é o do autoconhecimento, para pintar o retrato de uma natureza divina em geral, a qual não mais comporta ou não pode exercitar a fala falsa ou mentirosa, querendo ser benéfica aos homens? ${ }^{11}$

Aquilo que, aos olhos da tradição, pode aparecer como limitação incompatível com o poder absoluto dos deuses, mostra-se agora em sua faceta positiva: a mentira não mais se coaduna com a natureza divina, o mesmo valendo para punições aos humanos. E não será descabido sugerir que, no breve episódio de Delfos da Apologia, germinam já as principais características do divino que o segundo livro de A República vai formular, como "modelos a usar (týpoi) quando se fala sobre os deuses (perì theologías)", modelos segundo os quais "deve-se sempre...reproduzir a figura do deus justamente como ele é (hoîos tygkhánei ho theòs ón), quer em versos épicos, líricos ou trágicos (en épesin...en mélesin...en trago (i) día(i))" (379a): "o deus (ho theós) é essencialmente bom (agathòs...tô(i) ónti) (379a); “o deus (ho theós), já que é bom (epeidè agathós), não seria responsável (aítios) por tudo...quanto aos ma-

11 Sobre o fato de Apolo nunca ser nomeado e como isso pode ser interpretado como forma de fazer a crítica da religião tradicional - dando, inclusive, sentido à acusação de que Sócrates "não acreditava nos deuses da cidade" -, cf. Burnyeat, 2005. Para Burnyeat, essa ausência do nome de Apolo sugere uma posição monoteísta de intenções críticas e até mesmo explica a condenação: em sentido significativo, é certo que Sócrates não acreditava nos deuses em que acreditava a cidade (cf. p. 152-3). 
les (tôn kakôn), devemos procurar outras causas (átta...aítia), mas não o deus (all'ou tòn theón) (379c), de modo que "uma das leis e dos modelos (tôn perì theoùs nómon te kaì týpon) aos quais devem conformar-se quem faz essas narrativas e quem as cria é a seguinte: $\mathrm{O}$ deus não é causa de tudo, mas causa dos bens (mè pánton aítion tòn theón, allà tôn agathôn)" (380c); "é impossível (adýnaton).. que também um deus (kaì theô(i)) queira mudar a si mesmo (hautòn alloioûn), mas, ao que parece, sendo muito belo e muito bom (kállistos kaì áristos ón), dentro do possível (eis tò dýnaton), cada um deles (hékastos autôn) simplesmente permanece sempre na forma que lhe é própria (ménei aeì haplôs en tê(i) hautoû morphê(i))" (381c); "o deus (ho theós) é completamente simples e verdadeiro (komidê(i)...haploûn kaì alethés) em seus atos e palavras (én te érgo (i) kaì en lógo(i)), ele próprio não se transforma (oúte autòs methístatai) e não engana aos outros (oúte állous exapatâ(i)), nem com aparições (oúte katà phantasías), nem com palavras (oúte katà lógous), nem com envio de sinais, quer em vigília quer sonhando" (382e $)^{12}$.

Esse momento maduro do platonismo, no qual impera o tom normativo e parece predominar a visão monoteísta, claramente estabelecendo impossibilidades para o divino e conferindo-lhe um conjunto de características necessárias e essenciais, terá talvez no episódio de Delfos sua primeira versão, ainda embrionária, mas já consciente da importância primeira que uma nova forma de pensar deve conferir à reflexão sobre o conceito de divindade ${ }^{13}$.

12 Tradução em Platão, 2006. Ligeiramente modificada em 382e, com a inclusão de "verdadeiro". Texto grego de Platão, 1981.

13 A afirmação socrática de que ao deus não é permitido mentir, embora contrarie característica típica do mundo homérico, não pode ser tomada por absolutamente original ou inédita. Para ficar no caso de Apolo, já Píndaro se referia a ele como proibido de "tocar o falso" (tòn ou themitòn pseúdei thigeîn) (Pítica 9, v. 42). Há que ressaltar, portanto, que, neste caso como em outros, o Sócrates da Apologia faz parte de uma linha de desenvolvimento de uma nova maneira de conceber o divino. (O registro da passagem de Píndaro, a propósito da frase socrática, encontra-se em Goldman, 2009, que observa também que a "piedade" socrática, resultante do episódio, retoma ideias presentes em afirmações de Baquílides e Simônides. Cf. p. 456). Lembre-se também o caso importante de Xenófanes, que fazia contundente crítica aos deuses de Homero, em virtude de suas atitudes moralmente condenáveis (cf. DK 11 e 12), sustentando um deus único e imutável (cf. DK 23, 24 e 26). Em face de tudo isso, importa, sobretudo, reiterar que a novidade da posição socrático-platônica não está, aqui como em outros momentos, especificamente no conteúdo, mas no significado que o mesmo ganha, quando inserido no contexto do episódio. Neste caso, por exemplo, o fato de ao deus não se permitir que falte com a verdade não é simples ponto de autoridade, é algo que necessita ser estabelecido como consequência do processo refutativo e com ele harmonizado. A verdade da proposição "não é lícito ao 
Nesse sentido, não me parece absurdo, para comentar o significado do deus do episódio de Delfos, recorrer também à conhecida definição de piedade que a personagem Eutífron, no diálogo de mesmo nome, apresenta a Sócrates: "o que é do apreço dos deuses (tò mèn toîs theoîs prosphilés) é piedoso (hósion), e o que não é do apreço (tò dè mè prosphilés), ímpio (anósion)" (6e $)^{14}$. Embora aprecie a forma da resposta, que, ao menos, consegue ser mais do que a afirmação de um caso particular, Sócrates vai submetê-la a uma série de objeções, que levarão Eutífron, finalmente, a reconhecer-se em contradição, admitindo algo que, num dado momento, passara a recusar (cf. 15b-c). Eis o contumaz refutador em ação, aqui como em vários outros diálogos. Mas vale a pena observar que uma das dificuldades postas por Sócrates a Eutífron está na conhecida pergunta: "será que o piedoso - porque é piedoso é apreciado pelos deuses (tò hósion hóti hósión esti phileitai hypò tôn theôn), ou porque é apreciado é piedoso (hóti phileîtai hósión esti)"? (10a). A questão levantada por Sócrates visa a problematizar a definição mencionada, sem que se pretenda defender nenhuma das partes da disjunção. Basta-lhe mostrar ao sacerdote, um pretenso conhecedor da prática religiosa e piedosa, que sua definição - de resto, evidentemente em sintonia com a tradição e a opinião comum sobre os deuses -, não resiste àquela questão, e que Eutífron é incapaz de se explicar satisfatoriamente. Ora, se passarmos do contexto refutativo desse diálogo para nosso episódio da Apologia, talvez possamos afirmar que nele vigora resolutamente uma das partes da disjunção: sendo o divino, de algum modo, sujeito a certas verdades que o ultrapassam, parece fazer sentido concluir que o Sócrates da Apologia admitiria a tese de que o piedoso é apreciado pelo deus, porque é piedoso, e não o contrário. Tese plenamente compatível com sua crítica à concepção tradicional do divino e com a ideia reformadora que quer propor $^{15}$.

Mas isso nos reconduz ao problema da defesa socrática. Será ela eficiente no tribunal, se compreendida nesses termos? A resposta não é simples. Por um lado, o episódio culmina com atitude piedosa da parte de nosso filósofo; por outro, vincula essa piedade e obediência a uma visão crítica dos valores religiosos e teológicos

deus mentir", encerrada a investigação, ganha sua justificação, e isso faz toda a diferença, segundo as intenções que movem a narrativa do episódio.

14 Tradução em Platão, 2008. Texto grego de Platão, 1970.

15 Para Burnyeat (Burnyeat, 2005), a crítica socrática à religião e à piedade no Eutífron está em consonância com o ataque da Apologia. Quando Sócrates conduz Eutifron a admitir que aos deuses agrada o piedoso porque é piedoso, e não o contrário - o piedoso ser piedoso por agradar aos deuses -, ele segue a mesma ideia de divindade e, consequentemente, de piedade da Apologia e de República II (cf. p. 158, 160). 
tradicionais. A defesa é, portanto, mais do que uma simples defesa, é também um ataque e uma proposta positiva. Para Sócrates, a recusa da religião e teologia da cidade implica uma nova versão religiosa e teológica, construída em linhas gerais no episódio, e essa construção será objetivo tão ou mais importante do que aquela crítica e do que a própria defesa ${ }^{16}$. Eis por que, para o filósofo, a acusação será falsa: ele crê, sim, nos deuses da cidade, mas lhes dá novo sentido - e isso, aos ouvidos atenienses, significa não crer nos deuses da cidade. A complexidade da posição do filósofo se expressa categoricamente numa das mais importantes afirmações de sua defesa: "eu creio, varões atenienses, como nenhum dos meus acusadores crê (nomízo...hos oudeìs tôn emôn kategóron)" (35d). Note-se que, literalmente, Sócrates qualifica sua crença, referindo-se ao modo (hos) como crê. Sabemos que sua crença, afinal, diz respeito a um deus que não mais corresponde à tradição, e que tal crença, embora já presente antes do episódio do Oráculo, resulta diferente, como que legitimada por uma atividade investigativa e refutativa que incidiu sobre o próprio deus, o qual, agora, se impõe à crença, porque a verdade de sua sentença aparece como irrefutável. Em certo sentido, pode-se dizer que estamos diante de uma espécie de "religião racional", de religiosidade agora chancelada pela racionalidade humana, sem que haja ameaça à superioridade divina, que, benfazeja, quer que o humano entenda por que deve crer nela ${ }^{17}$.

O esboço de teologia da narrativa de Delfos insulta a cidade, consistindo em polêmico desafio aos deuses tradicionais. A tarefa do filósofo é, portanto, ár-

16 A ideia de que o discurso de Sócrates na Apologia não se limita a ser simples defesa do acusado também é defendida por Burnyeat (Burnyeat, 2005). Este autor considera que o deus do episódio do Oráculo, exortando os mortais à virtuosa consciência da ignorância, constitui clara resposta crítica aos valores cultuados na cidade. A tese, mostra Burnyeat, é mais antiga do que se imagina, a julgar pelo comentário feito no tratado denominado Perì eskhematisménon (algo como "sobre discursos em estilo figurado"), de autor e época desconhecidos, preservado por Dioniso de Halicarnasso, e que vê na Apologia, além de sua intenção apologética óbvia, conforme a qual se elabora o elogio de Sócrates como parte da defesa, uma acusação aos atenienses, e aquele que seria o objetivo mais importante, a exortação em favor do tipo correto de filósofo (cf. p. 154). Nesse sentido, um deus dotado de compromissos morais rígidos, como parece ser o caso na narrativa de Delfos, faz a crítica da tradição e torna possível até mesmo compreender a condenação, ainda que injusta.

17 O emprego de expressões como "religião racional" ou "crença racional" não nos deve conduzir necessariamente a algum tipo de dicotomia excludente entre "razão secular" e "superstição religiosa irracional”. A "crença racional” de Sócrates não precisa ser compreendida como resultado de uma simples redução do fenômeno religioso a critérios racionais. Para uma forma de criticar tal dilema, cf. Bussanich, 1999, especialmente p. 37-8. 
dua, como árdua se tornou sua investigação dos sábios, por ele comparada a trabalhos de Héracles (22a). Haverá melhor forma de introduzir a crítica e o novo modo de pensar, do que recorrer ao gênero discursivo considerado veículo por excelência da teologia a ser criticada - os mitos, tais como redesenhados na tragédia? Como expressar, para o leitor educado na tradição mais remota, a novidade, senão mostrando-a pelo prisma dessa mesma tradição, para, ao mesmo tempo, fazer-lhe a crítica ${ }^{18}$ ? Mas não se trata, bem entendido, de fazer uma "opção" por uma "forma" entre outras, a mais eficaz para transmitir um "conteúdo" singular, mas sim de aproveitar, conferindo-lhes novo significado, esquemas de pensamento que configuram uma visão de mundo, para propor sua profunda alteração ${ }^{19}$.

$* * *$

18 Não se trata de afirmar que o "socratismo" estabelecido e instaurado no episódio do Oráculo de Delfos consiste numa espécie de criação ex nihilo de uma "nova racionalidade", absolutamente inédita. A ideia de que a filosofia correta, aquela que Sócrates já praticava e agora praticará com mais convicção, nada mais é do que exame e investigação contínuos, e que é, por assim dizer, descoberta com a decifração e esclarecimento da verdade oracular, certamente bebe na fonte da própria tragédia. Basta lembrar o extraordinário caso do Édipo-Rei de Sófocles: do início ao fim, uma busca obstinada pela verdade. Uma análise detida dessa tragédia provavelmente nos mostraria que Édipo se serve de procedimentos argumentativos e investigativos que configuram um tipo de "racionalidade" típico da época, associado a diversas técnicas, artes e mesmo à nascente filosofia. Contudo, justamente esse lembrete nos aponta para a diferença fundamental: a investigação de Édipo o conduz a um destino trágico, que julgou, do alto de sua capacidade de resolver enigmas, poder evitar, enquanto a de Sócrates, se começa com a desmedida própria do herói trágico, vai-lhe proporcionar, com o esclarecimento da verdade, a conciliação com o deus. A semelhança entre a decifração do enigma do oráculo em Delfos e a investigação do Édipo sofocleano é observada por Goldman (Goldman, 2009, p. 453).

19 Para encerrar esta comparação com a Poética, registrem-se mais algumas aproximações possíveis. As definições de "peripécia" (peripéteia) e "reconhecimento" (anagnórisis) não são incompatíveis com o que ocorre em nosso episódio: "Peripécia' é a mutação dos sucessos no contrário (he eis tò enantion tôn prattoménon metabolé), efetuada do modo como dissemos; e esta inversão deve produzir-se, também o dissemos, verossímil e necessariamente" (1452a22-4). No episódio do Oráculo, há evidentemente uma inversão, que altera completamente o significado da narrativa, quando Sócrates descobre o verdadeiro significado da sentença oracular. Além disso, nele encontramos requisito que Aristóteles julga indispensável, tanto para a peripécia, quanto para o reconhecimento: "É porém necessário que a peripécia e o reconhecimento surjam da própria estrutura interna do mito (ex autês tês systáseos tôu mýthou), de sorte que venham resultar dos sucessos 
As conjecturas acima foram desenvolvidas com base em pelo menos duas teses gerais, mais ou menos evidentes ao leitor ao longo deste trajeto.

Em primeiro lugar, recusou-se a ideia razoavelmente disseminada entre muitos leitores de Platão, mas também crescentemente debatida, de que a Apologia de Sócrates consiste num documento histórico stricto sensu, como se Platão a tivesse escrito no calor da hora, com o objetivo de deixar transcrito à posteridade, o mais fielmente possível, o discurso proferido por seu mestre no tribunal. Bem ao contrário, tratou-se de levar a sério a afirmação feita por Aristóteles, novamente na Poética, a respeito dos "discursos socráticos" (lógoi sokratikoí) como exemplos de imitação (mímesis) (cf. 1447b10-13). Com esse ponto de partida, foi possível a aproximação com a tragédia e a sugestão de que o episódio do Oráculo de Delfos consiste em engenhosa construção de um caráter filosófico paradigmático, construção que Platão pode perfeitamente ter reelaborado e aperfeiçoado ao longo de sua trajetória intelectual.

Em segundo lugar, sendo a Apologia uma forma de exortar em favor da vida e atividade filosóficas à maneira socrática, vida e atividade essencialmente divergentes dos valores e ideias que configuram a cidade, essa exortação, para se afirmar, precisa ao mesmo tempo fazer a crítica das formas culturais e discursivas vigentes e emergentes, nas quais os valores da tradição se plasmam e sedimentam. Como a obra socrático-platônica está enraizada em nossa mentalidade filosófica, corremos o risco de esquecer que também ela teve sua certidão de nascimento, e que, para se afirmar, inevitavelmente polemizou com as diversas formas de discurso, sobretudo a poesia, e com a mentalidade que nelas prevalece. Assim, seu caráter essencialmente mimético se deve a sua intenção: alcançar o leitor formado nessa

antecedentes (ek tôn progegeneménon...gígnesthai), ou necessária ou verossimilmente (è ex anágkes è katá tò eikós)" (1452a14-20). No caso do reconhecimento, a relação de Sócrates com o deus parece poder ser bem comentada na definição: "O 'reconhecimento', como indica o próprio significado da palavra, é a passagem do ignorar ao conhecer (ex agnoías eis gnôsin metabolé), que se faz para amizade ou inimizade (eis philían è eis ékhthran) das personagens que estão destinadas para a dita ou para a desdita (tôn pròs euthykhían è dystykhían horisménon)" (1452a29-32). A diferença principal, como também no caso da peripécia, estará talvez na temporalidade: não se trata de aludir, no episódio socrático, a um momento pontual em que se dá a reviravolta. Embora certamente tal momento esteja implícito, a reviravolta resulta de um amplo processo de investigação e autoconvencimento, típico, aliás, do êthos socrático e em acordo com a estrutura da narrativa. Há, portanto, com a descoberta da irrefutabilidade do oráculo, uma "passagem do ignorar ao conhecer" que conduz à philía entre Sócrates e o deus. 
monumental tradição, falando-lhe criticamente sobre essa mesma tradição, mas por meio dela.

Assim sendo, pode-se ao menos compreender por que Platão, um notório crítico dos poetas, se mostra, também ele e à sua maneira, um poeta. No caso do nosso episódio de Delfos, parece que o filósofo se fez trágico, para, em seguida, poder ser, na mesma medida, antitrágico.

\section{REFERÊNCIAS BIBLIOGRÁFICAS}

Aristóteles. Poética. Tradução de Eudoro de Souza. São Paulo: Abril, 1973. . Poética. Edição trilíngue. Tradução de V. G. Yebra. Madrid: Gredos, 1974.

. "Art" of Rhetoric. Tradução de J. H. Freese. London: William Heinemann, 1975.

BuRnyeat, M. The Impiety of Socrates. In: Kamtekar, R. (ed.). Plato's Euthyphro, Apology, and Crito. Critical Essays. Lanham: Rowman \& Littlefield, 2005. p. 150-62.

Bussanich, J. Socrates the Mystic. In: J. J. Clearly (ed.). Essays in Honour of John Dillon. Ashgate, 1999, p. 29-50.

Goldman, H. Traditional forms of wisdom and politics in Plato's Apology. Classical Quarterly v. 59, n. 2. p. 444-67, 2009.

Hesíodo. Teogonia. A origem dos deuses. Estudo e tradução de Jaa Torrano. São Paulo: Roswitha Kempf, 1976.

Platão. Apologia de Sócrates, Eutífron, Críton. Tradução de André Malta. Porto Alegre: L\&PM, 2008.

. A República. Tradução de Anna Lia A. de Almeida Prado. São Paulo: Martins Fontes, 2006.

. Hippias Mineur - Alcibiade - Apologie de Socrate - Euthyphron - Criton. Tradução e estabelecimento de texto por M. Croiset. Paris: Les Belles Lettres, 1970.

. La République. Tradução estabelecimento de texto por E. Chambry. Paris: Les Belles Lettres, 1981. 
Abstract: This text intends to analyse the well known narrative on Delphic Oracle, in order to show that it is an example of platonic way of making the criticism of traditional discourses and their turn of mind, for defending his own ideas and philosophy.

Keywords: Philosophy, tragedy, divinity. 